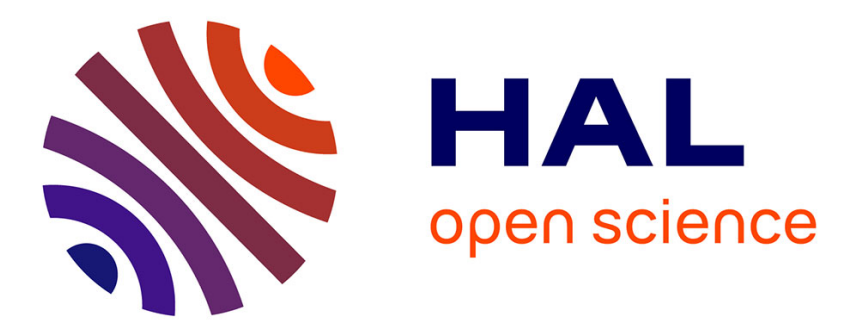

\title{
Greek Ambassadors and the Rhetoric of Supplication. Some Notes \\ Francesca Gazzano
}

\section{To cite this version:}

Francesca Gazzano. Greek Ambassadors and the Rhetoric of Supplication. Some Notes. KTÈMA Civilisations de l'Orient, de la Grèce et de Rome antiques, 2019, La rhétorique de la diplomatie en Grèce ancienne, 44, pp.53-69. halshs-02444284

\section{HAL Id: halshs-02444284 https://shs.hal.science/halshs-02444284}

Submitted on 17 Jan 2020

HAL is a multi-disciplinary open access archive for the deposit and dissemination of scientific research documents, whether they are published or not. The documents may come from teaching and research institutions in France or abroad, or from public or private research centers.
L'archive ouverte pluridisciplinaire $\mathbf{H A L}$, est destinée au dépôt et à la diffusion de documents scientifiques de niveau recherche, publiés ou non, émanant des établissements d'enseignement et de recherche français ou étrangers, des laboratoires publics ou privés. 

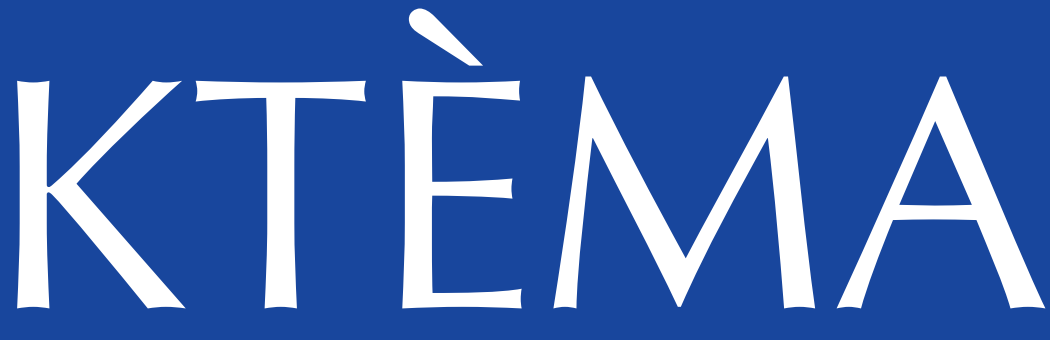

\section{CIVILISATIONS DE L'ORIENT, DE LA GRÈCE ET DE ROME ANTIQUES}

\section{La rhétorique de la diplomatie en Grèce ancienne}

Cinzia BeARzot, Laura Loddo

Laura LoDDo

Cinzia BeArzot

Paolo A. Tuci

Francesca Gazzano

Nicholas D. Cross

Davide Amendola

Jonathan R. W. PraG

Lorenzo CAMPAGNA

Cristina SORACI

Edith Foster

Walter LAPINI

Sylvain PERROT

Gianpaolo Urso

Anne JACQuemin
Political Exiles and Their Use of Diplomacy in Classical Greece

À propos du parallélisme entre deux discours d'ambassade à Sparte (Xén. Hell. V, 2, 12-19 et VI, 1, 4-16). 23

The Speeches of Theban Ambassadors in Greek Literature (404-362 B.C.)................ 33

Greek Ambassadors and the Rhetoric of Supplication. Some Notes ............................ 53

The (Im)balance of Power. Demosthenes' Complex Case

for an Alliance with the Megalopolitans.....

Presbeutikoi and Enteuktikoi Logoi in Hellenistic Interstate Relations.

Some Further Thoughts from an Epigraphical Perspective (c. 306-205 B.C.). 87

\section{Sicile hellénistique et romaine}

I.Sicily, Open Scholarship, and the Epigraphic Landscape of Hellenistic/Roman Sicily.

Trasformazioni urbanistiche in Sicilia alle origini della Provincia.

Riflessioni sul ruolo di Roma.....

Cultes et politique dans la Sicile du i ${ }^{\text {er }}$ siècle av. J.-C.

Le cas de la Vénus Érycine et de la Cérès d'Henna

\section{Varia}

Athens' Political Failures in the Central Chapters of Book 4 of Thucydides 163

Note interpretative e testuali alla col. XXII del Papiro di Derveni

La place de la musique dans la politique culturelle de Téos

dans la première moitié du $\mathrm{II}^{\mathrm{e}}$ siècle avant notre ère

Catilina legatus. Considerazioni su un discusso frammento sallustiano.

La dédicace aux Muses d'Eurydice fille de Sirrhas

(Plutarque, Sur l'éducation des enfants, 20) 


\section{Greek Ambassadors and the Rhetoric of Supplication Some Notes*}

RÉsumÉ-. Dans ces remarques préliminaires sur le rôle des émotions dans la pratique diplomatique grecque, on se concentrera sur une étude de cas: la rhétorique de la supplication pratiquée par les ambassadeurs dans le monde grec à l'époque classique. Bien qu'elle soit largement attestée dans les plaidoyers et dans le théâtre, qui partagent des traits bien connus avec les discours diplomatiques grecs, la supplication est peu utilisée par les ambassadeurs grecs; apparemment, son emploi n’a jamais réussi. Les quelques cas attestés partagent néanmoins des caractéristiques récurrentes, notamment le renvoi au passé à travers une mémoire partagée; cet expédient rhétorique s'avère une stratégie particulièrement utilisée pour susciter des émotions. L'article revient sur l'appel des ambassadeurs platéens aux juges spartiates en 427, tel que relaté par Thucydide, sur le Plataïque d'Isocrate, écrit en 373 et sur le Presbeutikos logos, discours apocryphe attribué à Thessalos, fils d'Hippocrate de Cos.

MотS-CLÉS-. ambassadeurs, diplomatie, discours diplomatiques, supplication, émotions, mémoire

Aвstract-. This paper aims at making some preliminary remarks about the role of emotions in Greek diplomatic practice, using the rhetoric of supplication as a test case. Although supplication is widely attested both in oratory and drama, genres that share well-recognized traits with Greek diplomatic speeches, it was seldom used by ambassadors, and it appears usually unsuccessful. A few instances of speeches of this kind are preserved, and they seem to share recurring features, among which the connection between the supplication and the rhetorical use of the past to arouse emotions turns out to be particularly relevant.

KEYwORDS-. diplomacy, ambassadorial speech, supplication, emotions, memories

The study of emotions in the ancient world has recently emerged as one of the most active and promising fields of research, in history and philosophy as well as in literature and art ${ }^{1}$; several

${ }^{*}$ ) A preliminary version of this paper was presented at the XI Celtic Conference in Classics (St Andrews, July 12th-13th, 2018), and I am grateful to Cinzia Bearzot and Laura Loddo for the invitation to participate in their panel, as well as to Emmanuelle Caire, Davide Amendola and Alessandro Brambilla for their useful comments and suggestions. Thanks to Dominique Lenfant and the Committee of Ktèma for accepting the article for publication, and to the anonymous readers, whose critical remarks helped me to clarify (I hope) some issues. I owe a special debt of gratitude to Walter Lapini, who read drafts and talked through ideas: he may not be aware of how helpful his encouragement and insightful feedback have been. All the dates are BC, unless otherwise stated. The English language revision of this essay is by Edward Tosques.

(1) A seminal work is Fortenbaugh 1975 (2nd ed. 2002 on Aristotle); more recently, Konstan 2006. In general, see the essays collected in: Chaniotis 2011; Chaniotis 2012; Chaniotis, Ducrey 2013; Cairns, Fulkerson 2015; Cairns, Nelis 2017. On specific aspects see Tsingarida 2001; LaCurse Munteanu 2012; Harder, Stöppelkamp 2016; Chaniotis, Kaltsas, Mylonopoulos 2017. 
topics - and many emotions (among others pity, fear, envy, anger, confidence, shame) ${ }^{2}$ - have been explored with ground-breaking results, making possible a better understanding of their role in the political life and social relations of ancient Greece. At the opposite end of the chronological spectrum, also in International Relations studies new research trends have highlighted the deep impact of emotional dynamics in international politics; ${ }^{3}$ as for diplomatic negotiations, "emotional diplomacy" is now considered a form of strategic action, namely the official deployment for political ends of emotional displays at the international level. ${ }^{4}$ Within the same "emotional context", but at another level, face-to-face diplomacy is being recognized as of the utmost importance, because it enables practitioners to exchange individual expressions of intentions-and by extension, the intentions of the government they represent-that are otherwise lost, attenuated or distorted if communications were to occur through other impersonal and irregular channels. ${ }^{5}$

Curiously enough, a wide-ranging study of emotions in ancient Greek interstate relations is still lacking, although some recent papers-such as Angelos Chaniotis' essays on emotions in inscriptions and historiography, ${ }^{6}$ and Maria Fragoulaki's works on Thucydides ${ }^{7}$-offer valuable insights.

In what follows, I would like to make some preliminary remarks in this direction, using the rhetoric of supplication in diplomatic speeches as a test case. The choice calls for a brief explanation: generally speaking, supplication is one of the most poignant acts, meant as it was to arouse feelings of pity, mercy and empathy in the supplicandus. ${ }^{8}$ Anyway, in the world of Greek poleis diplomacy and supplication seem to be concepts that were mutually exclusive, or at least that were hard to combine. ${ }^{9}$ In fact, while diplomacy is by definition the realm of exchange and reciprocity, the recognized place of negotiation and mediation, ${ }^{10}$ supplication is instead a (mostly) individual practice with legal, ethic, and religious elements, which involves no discussion, no negotiation, no intention whatsoever to find a "common ground"; the suppliant has nothing to offer, no deal

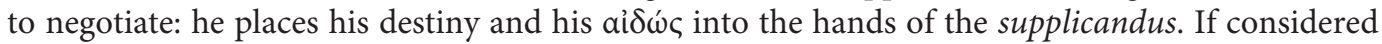
in this perspective, it might seem peculiar-at least at first reading-to find the language, if not the gestures, of supplication in historical diplomatic contexts and speeches as they are reported by Greek authors, and that are not referring only to a last-minute effort to escape destruction on the battlefield. A possible way to assess the rhetorical and emotional role of supplication in ambassadors' speeches may be the comparison with two literary genres where acts of supplication are instead well attested, and that share several features in common with Greek diplomatic practice, namely drama and judicial oratory. As a matter of fact, the ambassadors had often to speak in a highly theatrical and performative dimension, because Greek diplomacy had an essentially public and oral nature; also, ambassadors' main purpose - to persuade the audience - was the same as for

(2) On the definition of "emotion" and the difficulties in the conceptualization of comparable phenomena in ancient cultures, see Konstan 2006, p. 3-40; Cairns 2008; Cairns, Fulkerson 2015, p. 3-40; Cairns, Nelis 2017, p. 7-18.

(3) See especially ClÉment, SANGAR 2018, with a full and up-to-date bibliography.

(4) Hall 2015.

(5) Wong 2016.

(6) See Chaniotis 2012a-b; Сhaniotis 2013a-d; Chaniotis 2015.

(7) See Fragoulaki 2013; Fragoulaki 2016.

(8) On supplication in the Greek world, see Gould 1973, Giondano 1999 (on Homer), and especially NaIden 2006, also for the use of the term supplicandus. On gestures of supplication in Greek art see now Pedrina 2017. As for the role of aỉ $\omega$ c in supplication, see CAIRNs 1993, esp. p. 113-119; 189-193; 221-227; 276-287.

(9) This paper is devoted to "classical" Greek diplomacy: about the diplomatic relations between the Greek poleis (and leagues) and Rome, when supplication became a widely used practice before the Roman authorities, see LINDERSKI 1995 (=2007), Canali de Rossi 1997, and the essays in EILers 2009.

(10) See e.g. Jönsson, Hall 2005. 
orators and tragic characters. These connections seem worthy of examination: here, for reasons of space, the analysis will be confined to three specific, albeit interrelated, issues of the topic.

The first point will briefly take into consideration the combined role of emotions and supplication in oratory and tragedy, the second one will discuss the relationship between ambassadors and supplication, and the third and last one will be devoted to a test sample from some supplicatory speeches in diplomatic contexts.

\section{EMOTIONS AND SUPPLICATION IN ORATORY AND TRAGEDY}

As is widely acknowledged thanks to numerous studies, emotions-which Aristotle describes as "all those feelings that so change men as to affect their judgements"11-played a part of paramount importance in Greek courtrooms and assemblies. ${ }^{12}$ Even more powerful, and intimately linked with the dramatic genre, was their impact on the theatrical scene. ${ }^{13}$ In this perspective, it is noteworthy that rituals of supplication also played a major part in exactly the same contexts, at least at Athens. As for oratory, there is no need here to insist on the intimate relationship between emotions, eloquence and persuasion in classical orations, ${ }^{14}$ nor to recall the occurrence of supplications in Athenian courts. As Steven Johnstone has noted, there are nineteen instances in extant orations where speakers supplicate the jury, and fifteen where prosecutors anticipate that their opponents will do so. ${ }^{15}$ Other than that, the fact that the habit of weeping and supplicating before jurors is mocked by Aristophanes in his 424 Wasps seems to point to its frequency in courtrooms. ${ }^{16}$ In the same vein, the author of the Pseudo-Xenophontic Athenaion Politeia claimed that even defendants from allied cities had to supplicate before the Athenian courts. ${ }^{17}$ Not surprisingly, another author who criticizes the practice of supplication before a jury is Plato, whose alter ego Socrates condemns anyone who has "begged and supplicated the jurors with many tears and brought forward his children to arouse pity", because he "brings disgrace on the state". ${ }^{18}$ Similarly, although not in the same way, nor with the same aim of oratory, ${ }^{19}$ the tragic stage was the "place of emotions"

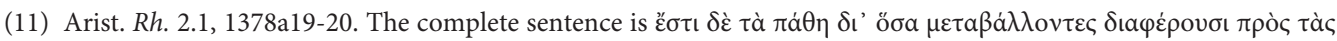

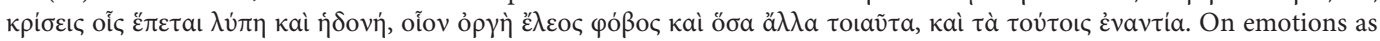
described by Aristotle see especially Fortenbaugh 1970 (=2006, p. 9-38); Fortenbaugh 1975 (II ed. 2002); FortenbaUgh 2007. The most comprehensive analysis is that of Konstan 2006, who remarks (p. 27) that "Aristotle's most extensive treatment of the emotions is to be found in his treatise on rhetoric rather than in his book on psychology (On the Soul)": this notation helps to better understand the importance given by the Greeks to the relationship between words and emotions.

(12) See Konstan 2006, p. xiii: "The emotions, as opposed to drives and appetites, depend on the capacity for symbolization. For the Greeks, persuasion was central to the idea of an emotion, whether in the law courts, in political assemblies, or in the various therapies that relied on verbal interactions to change the judgments that are constitutive of the passions". On emotions and rhetoric, see Konstan 2007; on their use in courtrooms see now GotTESMAN 2014; CAREY 2016; Griffith-Williams 2016; SANDERs 2016.

(13) See e.g. Stanford 1983; LanZa 1997; Konstan 1999; Meineck 2017.

(14) See Kennedy 1993 and the essays collected in Worthington 1994.

(15) Johnstone 1999, p. 148-170. See also Gottesman 2014, p. 94-99.

(16) Ar. Vesp. 555-559; 568-573. See also the parody scene (the trial of Labes the dog) at 976-978.

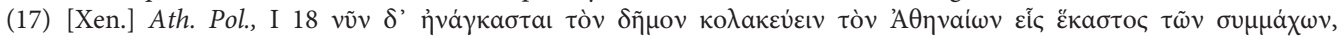

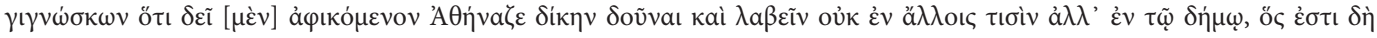
vó commentary of LAPINI 1997, p. 134-137, who convincingly states that the expression " $\dot{\varepsilon} \nu \tau \tilde{\omega} \delta \dot{\eta} \mu \omega$ " indicates the courtrooms, and not-as it may seem-the assembly. On the relationship between supplication and judicial oratory, see ZeLNICKAвramovitz 1998, and especially Johnstone 1999, p. 155-165; GotTesman 2014, p. 86-113.

(18) Plat. Ap. 34c-35a.

(19) On the differences between oratory and tragedy in using the language of emotions and the rituals of supplication, see especially JoHnstone 1999, p. 166-169. 
par excellence ${ }^{20}$ : many different emotions were displayed on the stage by actors as well as by

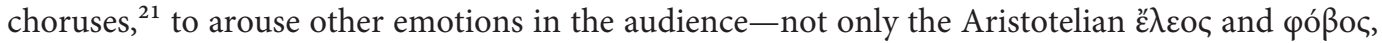
as scholarship has made clear. ${ }^{22}$ To quote Marianne McDonald, in tragedy "arguments persuade by appeals to reason, the senses, and the emotions". ${ }^{23}$ Likewise, in tragedy, and to a lesser extent also in comedy, supplication figures in several of the extant plays. As for tragedies, the centrality of this theme is at times already clear from the title, as in the The Suppliant Women of both Aeschylus and Euripides ${ }^{24}$ but supplication scenes can be found in many tragedies and comedies. ${ }^{25}$ They have been conveniently listed by Fred Naiden in his volume on Ancient Supplication, ${ }^{26}$ whose Appendix 1 offers more than sixty ritual acts in the extant plays. ${ }^{27}$ Moreover, in another recent book, City of Suppliants, ${ }^{28}$ Angeliki Tzanetou argues that three specific "suppliant plays", ${ }^{29}$ namely Aeschylus' Eumenides, Euripides' The Children of Heracles and Sophocles' Oedipus at Colonus, were specifically aimed at portraying Athens as the "city of justice", one that assisted the marginalized and oppressed, that showed compassion and generosity towards strangers asking for help. ${ }^{30}$ In her view, supplication in these dramas was deliberately exploited to foster an ideological and ethical underpinning for Athenian political and military hegemony over the member states of the Delian League. ${ }^{31}$ Therefore, "suppliant plays" should be read in the light of the relationship between Athenian imperial power and Athens' allies, before and during the Peloponnesian war. Of course, in Athenian civic ideology, Athens' altruism and generosity toward the weak, the wronged and the suppliants is a well-known and all-compassing topos, employed even to justify empire building, and it can easily be detected in many forms of Athenian art and literature, ${ }^{32}$ above all in the reshaping of Theseus' mythical figure and in funeral orations. ${ }^{33}$ In these instances, as well as in tragedy, for obvious reasons, this portrayal is embedded in a legendary past: through their "Tatenkatalog", ${ }^{34}$ and their mythical victories in wars, fought on behalf of others, fifthcentury Athenians endeavoured to assert their military superiority and legitimate their claim to leadership. ${ }^{35}$ This assumption gives the Athenian self-glorification a diplomatic twist, which it is important to underline ${ }^{36}$ : in fact, the rhetoric of the "city of justice" was sometimes exploited

(20) See supra, n. 13.

(21) This is especially the theme explored by VISVARDi 2015, who analyzes tragic choruses that enact fear and pity, and juxtaposes them to the Athenian demos in Thucydides' work.

(22) Taplin 1978, p. 117-124; Konstan 1999; LaCurse Munteanu 2012.

(23) McDonald 2007, p. 474.

(24) On Aeschylus' use of supplication in this tragedy, see especially GöDDE 2000.

(25) E.g., supplication scenes occur in Aeschylus' Eumenides, Sophocles' Oedipus at Colonus, Euripides' Medea, Heracles: a detailed analysis of all these dramas is GRETHLEIN 2003.

(26) NAIDEN 2006.

(27) NAIDEN 2006, p. 302 (Aeschylus), 307 (Aristophanes), 315-316 (Euripides), 335 (Sophocles).

(28) Tzanetou 2012.

(29) On the concept of "suppliant drama", see especially BERnEK 2004.

(30) As for this mythical image of Athens, see also Grethlein 2003; cf. Grethlein 2010.

(31) On this theme, see the useful discussion in GotTesman 2014, p. 86-99.

(32) On Athenian art, see especially Castriota 1992; the essays collected in Boedeker, RaAflaub 1998. On myth in rhetoric see GotTeland 2001; STEINBock 2013; GRethlein 2014.

(33) As for Theseus' image see Mills 1997; Servadei 2005; Shapiro 2012. On the epitaphios logos-apart from the classic Loraux 1986-see now Hanink 2013; Proietti 2015, with previous bibliography.

(34) On this term, see Proietti 2015.

(35) The use of this topos is attested also in the fourth-century Athenian sources, such as And. III (De pace) 13; Dem. XVIII 99. Other instances in Demosthenes: II 24; VIII 42; X 14; XIX 16-accusing his foe Aeschines to have even proposed

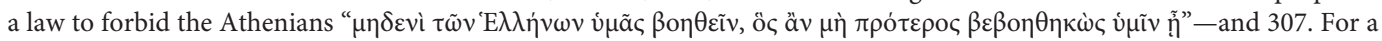
discussion see Hunt 2010, p. 172-180; CHRIst 2012, p. 163-176.

(36) The importance of the moral principle of "helping the wronged" in Greek interstate relations is positively discussed by Karavites 1984, and by Low 2007, p. 177-187; see now especially CHRIST 2012, p. 118-176. 
also by Athenian and foreign ambassadors. ${ }^{37}$ A famous instance of an Athenian envoy recalling his polis' reputation is Euphemus, who was sent to Camarina in 415. In his speech, as Thucydides relates it, he openly states that Athens has always helped the victims of injustice, ${ }^{38}$ and adds that by this very fact the possibility of an Athenian military intervention has prevented other powerful poleis from committing injustices against weaker ones. ${ }^{39}$ On the other hand, Thucydides reports that the Corcyraean envoys who in 432 requested from Athens an alliance and help against Corinth, in their peroration added the ethical argument of "bringing aid to the wronged" to the much blunter argument of economic and military interest. ${ }^{40}$ What is more, recalling the mythical past along the same lines of help given and received seems to have been a rhetorical strategy employed also in the speeches made by "suppliant ambassadors".

\section{GREEK AMBASSADORS AND SUPPLICATION}

However, before examining them, I must turn briefly to the second point, the relationship between ambassadors and supplication. ${ }^{41}$ In general terms, it is known that Greek diplomacy displayed several features in common with oratory on one hand and with drama on the other. ${ }^{42}$ In the Greek world, where international communication through written messages and letters was normally avoided, ${ }^{43}$ diplomatic activity was entrusted to ambassadors and envoys whose real mission-deprived as they usually were of firm authority to negotiate in the name of their polis $^{44}$ - was to seek to win over the audience, mostly city councils and assemblies, with public speeches, sometimes in the form of a debate with other delegations. ${ }^{45}$ Persuasion was therefore the main goal of ambassadors, ${ }^{46}$ and eloquence and rhetorical delivery must have been their key tools ${ }^{47}$ Moreover, the inter-Greek diplomatic system was embedded in reciprocity ${ }^{48}$ : even though it was historically uncommon for all the polities involved in a diplomatic intercourse to be on the same footing in terms of hierarchy or influence and power (as in the case of the relations between

(37) I wonder if the answer which, according to Herodotus (VI 108,3), king Cleomenes of Sparta gave to the Plataean envoys who had asked for Spartan protection- "We advise you to put yourselves under the protection of the Athenians,

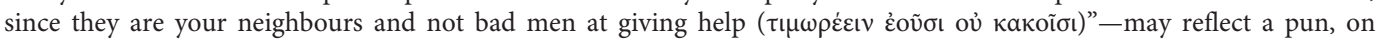
Herodotus' part, about the Athenian claim in his times. In Lionel Scott's opinion (Sсотт 2005, p. 376) Herodotus' sources for this episode were the Athenians themselves: in this case, the sentence would be another instance of the topos.

(38) Thuc. VI 87,2.

(39) Thuc. VI 87,4. On justice in Thucydides' Athenian speeches, see Heath 1990; on the exploitation of this theme by ambassadors see PICCIRILLI 2002, p. 92-98.

(40) Thuc. I 33, 1, with the commentary of Gomme in HCT I, 1945, p. 168.

(41) This issue has never been treated in itself by modern scholars. See the brief remarks in NAIDEN 2006, p. 56-58, who takes into consideration the religious/ritual aspect of supplication by envoys, connecting their act to a quest for inviolability and to the role of the herald (or to his absence).

(42) On these aspects of Greek diplomacy, see especially Gazzano 2016, with previous bibliography. On the connection between diplomacy and oratory, see also RuBinstein 2016.

(43) See recently, in this sense, CeCCARELLI 2013; cf. the general remarks of LAPINI 2013, p. 31-36 with n. 30. The author of these pages is writing an article about the use of letters in diplomatic communication during the Ionian War. On the relationship between letters and oral performances in later (Hellenistic) interstate practice, see RuBINSTEIN 2013.

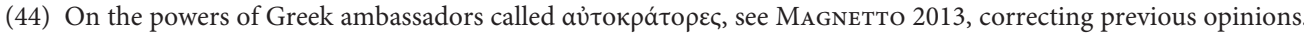

(45) On the character of Greek ambassadors see Kienast 1973, coll. 546-552; MosLey 1973, p. 30-36; PiCcirilli 2002, p. 23-28; GAzZANo 2016, p. 124-125, with previous bibliography.

(46) As for the importance of persuasion in diplomatic contexts see especially CHaniotis 2009; cf. Gazzano forthcoming; about its role in the 21th century diplomacy, see the essays collected in KurbaLIJa 2013.

(47) Cf. Rubinstein 2016.

(48) See notably Low 2007 , p. 33-76. Reciprocity appears to be a core normative theme running through all diplomatic history: JöNSSON, HALL 2005, p. 28-30. 
imperial Athens and her subjects), the diplomatic speeches preserved by historians show that the right to defend a position or an interest was generally recognized.

As Aristotle stated, emotions and ethics were central to all processes of persuasion, ${ }^{49}$ and this is certainly true, as far as drama and oratory are concerned: in tragedies and in court speeches emotional arguments appear often intertwined with moral issues. ${ }^{50}$ The use of moral arguments per se is also customary in the diplomatic arena: they were in fact often employed by ambassadors to enforce their statements. For example, it is well known that in Thucydides' speeches the ambassadors make conspicuous use of ethical concepts such as justice, loyalty or kinship. ${ }^{51}$ Anyway, among these, kinship seems to play a special role also for its emotional implications: as Maria Fragoulaki argues, Thucydides' envoys who refer to kinship relations reflected a concern for the "emotive and ethical parameters of the war", emphasizing the deep emotional impact that these kinds of ties added, in Thucydides' narrative, to interactions among related polities. ${ }^{52}$

These analogies notwithstanding, the use of supplication in diplomatic speeches seems to have been fairly rare, at least in classical times, in contrast to what happened in courts and on the theatrical stage. ${ }^{53}$ The reasons are evident: supplication, the traditional, venerable, widespread practice with legal, moral, and religious elements, was a sort of extrema ratio, by which one surrendered oneself up to somebody else, while-performing the ritual-asking for something: for shelter and protection, for example, or to be spared, or to receive help against someone else, and so

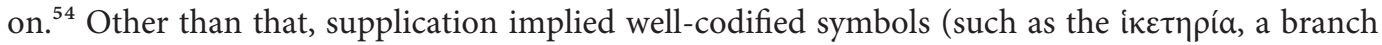
entwined with white wool and fillets ${ }^{55}$ ) and gestures, among which bending one's body to embrace the opponent's knees, or-on the battlefield - stretching forth one's hands as a sign of surrender, ${ }^{56}$ all gestures which are commonly recognized as "bio-sociological" signals of self-abasement, humility and desperation. ${ }^{57}$ Finally, acting as suppliant did not at all guarantee a positive answer, because denial was the more common reaction, and acceptance or rejection was all but arbitrary: so, the rejection of a suppliant was seldom considered a violation of ritual obligation. ${ }^{58}$ This conclusion

(49) Arist. Rh. I 2, 1356a 1-25. See also supra, n. 11, with bibliography; cf. LaURitzen 2014; Rubinstein 2016.

(50) On drama see e.g. Buxton 1982, p. 149-151 and especially Blundell 1989; on oratory see e.g. CAReY 1994; Griffith-Williams 2016. Cf. now LaCourse Munteanu 2017; Papaioannou, Serafim, da Vela 2017.

(51) Justice: e.g. Thuc. I 37-43 (Corinthian ambassadors at Athens); I 78 (Corinthians at Sparta): see Heath 1990; Morrison 1999; the issue of loyalty is central in Thuc. III 9-14 (Mytileneans at Olympia), as in the self-defence of the Plataeans before the Spartan judges (III 52-68): see OrwIN 1994, p. 64-86, and, on the last episode, infra. Role of kinship: Thuc. I 24-26 (Epidamnian envoys to Corcyra and Corinth: cf. Diod. XII 30, depending on Ephorus); III 86 (Leontinians at Athens); VI 6,2 (Aegesteans at Athens); VI 76,2 (Hermocrates of Syracuse as ambassador to Camarina); VI 88,7 (Syracusan

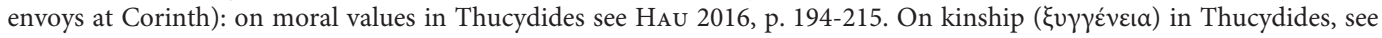
now Fragoulaki 2013. In general see Piccirilli 2002, p. 79-101; Usher 2007.

(52) Fragoulaki 2013 (quotation from p. 20). On kinship diplomacy see also Jones 1999; cf. Patterson 2010.

(53) On the connection between rhetoric and supplication in Homer see Giordano 1999, p. 41-69.

(54) See NAIDEN 2006, with previous bibliography; for a possible distinction between kinds of supplication (a "help me!" model different from a "spare me!" one) cf. PARKER 1983, p. 181-189, LionetTi forthcoming.

(55) For an example of its use in a "diplomatic" context see Hdt. V 51,1 (Aristagoras' "second chance" to talk to king Cleomenes): Branscome 2013, p. 136; cf. Hdt. VII 140-141 (Athenian envoys at Delphi): on both episodes, see infra.

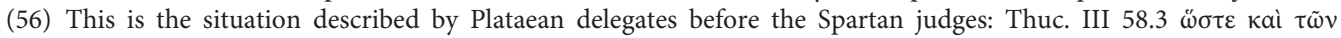

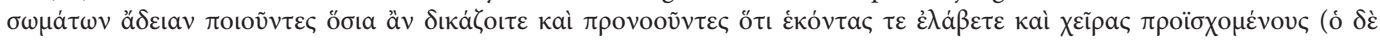

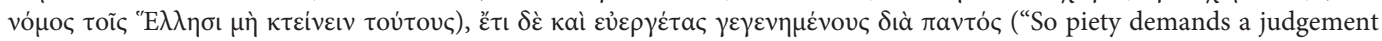
which grants us the safety of our lives and recognizes that we gave ourselves up to you freely, with our hands outstretched in supplication-and Greek law prohibits the killing of suppliants-, and recognizes too that we have always been your benefactors"; transl. Hammond). See MACLEOD 1997, p. 232-233 (= 1983, p. 108-109); cf. Debnar 1996. About supplication on battlefield: Gould 1973, p. 80-81 (in Homer); Bederman 2001, p. 51-59; NAIden 2006, p. 135-136.

(57) Gould 1973, p. 89.

(58) See especially NAIDEN 2006. 
rules out the possibility that supplication could be used by envoys as a way out in difficult situations, when all other arguments failed.

Nonetheless, Greek envoys were sometimes obliged to present themselves as suppliants. At Athens, supplication evolved over time, and-never losing its religious connotation-became a truly formal, legal practice, as Rachel Zelnick-Abramovitz has shown. ${ }^{59}$ We know from the Aristotelian Athenaion Politeia that one of the meetings of the Assembly was explicitly dedicated to supplications. ${ }^{60}$ Also, from fourth-century honorary inscriptions we can infer that foreigners who wanted to make their requests to the Athenian demos had to follow a specific supplication

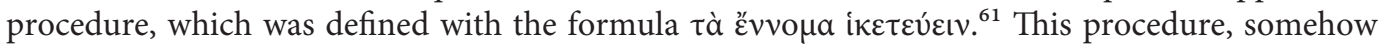
different from a simple "request" (ali $\eta$ бıৎ) known from other inscriptions, ${ }^{62}$ was followed not only by "private" foreigners: at least in one circumstance, official ambassadors, who as a rule had

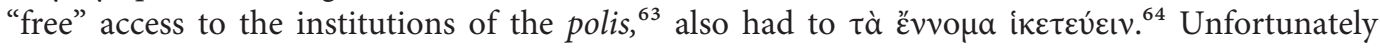
the poor state of the stele offers no indication as to why these ambassadors, who were from Keos, had to supplicate to be heard before the Athenian demos. ${ }^{65}$ An analogous situation, perhaps, is mentioned by Apollodorus [Demosthenes] ${ }^{66}$ : in about 350 ambassadors from Proconnesus went

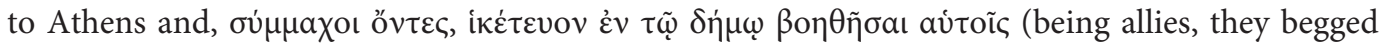
in the assembly to come to their aid). Previous cases of ambassador-suppliants are recorded only by literary sources. In Herodotus, the episodes of Aristagoras of Miletus, ${ }^{67}$ and of the Athenian envoys to Delphi show that supplication could be viewed as a "ritual way" to get a second chance, ${ }^{68}$ even if the example of Aristagoras is certainly misleading, because his subsequent behaviour was not that of a suppliant, since he simply tried to bribe the king. On the other hand, in Aristophanes' Lysistrata there is the vivid description of the Spartan envoy Pericleidas, who came to Athens in about 464 to beg for help after the Helot revolt, and is portrayed as a "suppliant before our altars, pale in his purple robes, praying for an army" ${ }^{69}$ This may be a comic exaggeration, but eventually Athens accepted Sparta's plea. ${ }^{70}$ Another instance, described by Thucydides, concerns

(59) Zelnick-Abramovitz 1998. See now also Gottesman 2014, especially p. 86-94, 101-113: it is noteworthy that he associates the formalization of supplication before the Council and the Assembly with the general return to the past that characterizes Athenian society in the 340s and 330s, when the memories of the past empire revived in the image of the city as protector of suppliants, familiar from tragedy and myth: see e.g. Isoc. IV 57-59.

(60) Arist. Ath. Pol. XliII 6, with Rhodes 1993, p. 527-528. See Zelnick-Abramovitz 1998, p. 563-564, and GotTESMAN 2014, p. 101-113, who considers it an innovation in Athenian procedure that originated between 353 and $c$. 330 (p. 101 and n. 2).

(61) See Zelnick-Abramovitz 1998, p. 563 and n. 28, for a catalogue. Cf. Gottesman 2014, p. 101-113.

(62) On the difference see GotTesman 2014, p. 101-113, who suggests "that the reason why some supplicated while others did not does not only have to do with the merits of their case or what they are asking for. [...] It has to do with who speaks on their behalf, and what they gain from the performance" (p. 108).

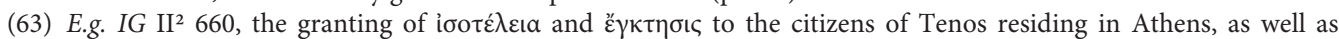
$\pi \rho$ ó $0 \delta$ oc, following the appearance of the ambassadors of Tenos in the Council (lines 1-24; after mid-fourth century): ZeLNiCK-ABRAMOVITZ 1998, p. 557.

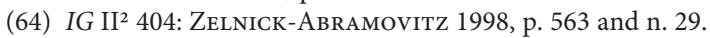

(65) See however COOPER 2008, p. 36-40, with a status quaestionis.

(66) [Dem]. L 5, with COOPER 2008.

(67) Hdt. V 50-51: the Milesian leader, unable to persuade Cleomenes during their second, and last, "official" interview, managed to enter his house by acting as a suppliant $(51,1)$. He does not supplicate, anyway, but offers money to bribe him $(51,2)$. This behaviour is particularly fitting with the negative presentation of his character by Herodotus: on this scene see now ZALI 2015, p. 43-44, 197-201.

(68) Hdt. VII 140-141, with the commentary of VANNicelLi 2017, p. 465-473.

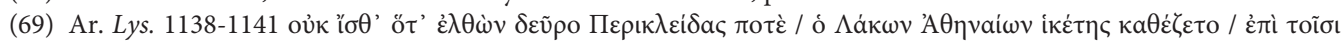

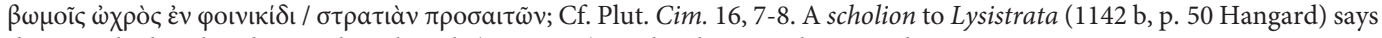

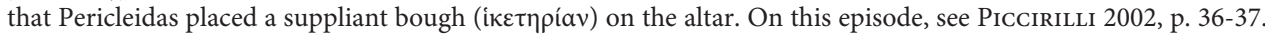

(70) Thuc. I 102; Plut. Cim. 16, 7-8: on the events, see ZaCCARINI 2017, p. 183-198. 
the ambassadors from Epidamnus, who in 433 went to Corcyra, "beseeching their mother country not to allow them to perish [...]. [7] The ambassadors seated themselves in the temple of Hera as suppliants, and made their requests [...]. But the Corcyraeans refused to accept their supplication, and they were dismissed without having effected anything". ${ }^{11}$ Also, the local exiled oligarchs, as Thucydides reports a bit later, went to Corcyra to beg for help- "pointing to the tombs of their ancestors, had appealed to their blood ties to restore them" "72: although the suppliants were $\varphi v \gamma a ́ \delta \varepsilon \varsigma$ and not official ambassadors, this time the Corcyraeans assented to their appeal. In this respect, it may be questioned if a large group of (political) exiled, ${ }^{73}$ such as the Thucydidean oligarchs from Epidamnus, was considered just as the sum of private individuals/suppliants, or could be perceived as a sort of "community in exile", especially in times of war, or stasis ${ }^{74}$ : certainly this happened in 411, when the Athenian fleet at Samos, not recognising any legitimacy to the official government of the Four Hundred, acted like a self-determining political entity, even receiving and sending ambassadors. ${ }^{75}$ The issue is too complicated to be addressed here, but a somehow similar case of unsuccessful ambassadors/suppliants sent by exiles is recorded also by Dinarchus: after the destruction of their city by Alexander, the surviving Thebans sent a group of envoys to the Isthmus, to ask the Arcadian mercenaries for help; the embassy "had reached them with difficulty by sea and was bearing a suppliant's olive-branch and heralds' wands plaited, as they said, from young shoots" ${ }^{76}$ The Arcadians welcomed the ambassadors, and pitied them for their misfortunes, but did not help them: "They made it clear that although they were constrained because of circumstances to follow Alexander with their bodies, in spirit they supported the Thebans and the freedom of the Greeks". ${ }^{77}$ It is noteworthy that the envoys sent by Theban exiles held two different symbolic objects, the hiketeria as suppliants, and the herald's wand as envoys: this herald's staff could be interpreted as a substitute for the herald himself, because his presence usually granted the immunity of the delegation. More important, as Fred Naiden has observed, ${ }^{78}$ here "the supplicandi are also supposed to act as a community that is receiving emissaries from another", even if the former were Arcadian mercenaries and the latter Theban refugees who were striving for diplomatic status.

A few instances might be added, but from these examples it may already be assumed that official envoys could indeed rely upon supplication; nonetheless, it is not clear why they chose or had to, even if we can guess that, as far as the embassies to Athens were concerned, supplication could be used as a legal "emergency procedure" (or maybe the only legal option) to get urgent access to the Athenian demos. The examples concerning envoys sent by exiled groups need to be further investigated, because their supplications may have had more than one purpose; however, official - as well as individual-supplication was not in itself a key to success, as is made clear by the Corcyraean rejection of the suppliant ambassadors from Epidamnus and the Arcadian refusal to help the Thebans.

In all these cases, however, we have no direct speeches. The third and last section of this paper will briefly take into account three diplomatic speeches that employ the language of supplication: namely the Plataean appeal to the Spartan judges in 427, as related by Thucydides; the Plataicus, Isocrates' plea written in c. 373 in the name of a Plataean embassy at Athens; and the apocryphal

(71) Thuc. I 24, 5-7: cf. Hornblower 1991, p. 68-69.

(72) Thuc. I 26, 3, with Hornblower 1991, p. 71, and especially Arnold 1992.

(73) From Thuc. I 26,1-2 can be inferred that the despatch of Corinthian colonists to Epidamnus was intended to supplement the citizen body, which had been depleted by the removal of the oligarchs (GARLAND 2014, p. 90).

(74) See especially Garland 2014, p. 57-78; Gray 2015 (for Hellenistic times). Cf. also Price 2009, 26-31.

(75) Thuc. VIII 86, 1 and 8, with Forsdyke 2005, p. 181-191; GARLand 2014, p. 68.

(76) Din. I 18 (transl. I. Worthington).

(77) Din. I 20 (transl. I. Worthington).

(78) NAIDEN 2006, p. 56-58 (quotation from p. 57). 
Presbeutikos logos, which purports to be held, again in the Athenian assembly, by Thessalus, son of Hippocrates of Cos, in behalf of his fellow citizens.

\section{DIPLOMATIC SUPPLICATIONS AND THE EMOTIONAL USE OF THE PAST}

Of course, any detailed discussion of these texts is out of the question here: my analysis will therefore be confined to a single aspect, already noted when considering the "suppliant dramas", namely the rhetorical use of the past to arouse emotions in the audience. ${ }^{79}$ All three speeches, though very different from one another, in fact share this common feature: they seek to build a bridge between past and present, ${ }^{80}$ linking the act of supplication to the memory of past deeds, whose remembrance ought to inspire a particular emotion, though not necessarily the same, in the supplicandi. Also, they appear to some extent comparable for other reasons: two are-or pretend to be-addressed to the Athenian assembly (Isocrates' and Pseudo-Hippocrates'); two (Isocrates' again and Thucydides') were written by Athenian authors, while the third is apocryphal, although a recent hypothesis by Eric Nelson assigns the authorship to the Coan historian Macareus, ${ }^{81}$ in the III century. ${ }^{82}$

Two discourses feature as speakers Plataean citizens, but while one is a famous plea for mercy before five Spartan judges in 427 (Thucydides), the other is a request to the Athenian people for military help against Thebes in about 373 (Isocrates). Also, while the reader knows that the

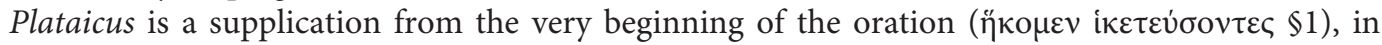

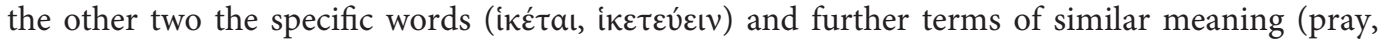
beg, etc.) occur later on, connected with the most moving arguments. Almost certainly, none of the three was ever delivered, none at least in the form we read them, and all of them failed: the supplications were rejected. Eventually, if we accept the idea that the "ambassadorial speech" as a distinct genre developed only in Hellenistic times, Polybius being the first historian to consider it a separate kind of speech different from other types of deliberative oratory, ${ }^{83}$ only the Presbeutikos, though apocryphal, ought to be taken into account. Nonetheless, I think all of them deserve to be analysed as documents of diplomatic interest.

To return to the main issue, in all three of these speeches we can find an "emotional" exploitation of the past that is closely linked to the act of supplication. In general terms, several scholars have emphasized that the evocation of the past was a powerful rhetoric tool in Greek drama (myth), oratory and also in diplomatic talks ${ }^{84}$ : as Angelos Chaniotis has shown, ${ }^{85}$ historical episodes from the past were frequently used in negotiations to persuade the audience. In his analysis he focuses on several topics, and demonstrates how much history was exploited by ambassadors, so to form the backbone of their Überzeugungsstrategie, as a logical, legal or moral argument, and even as a sort of ritual. Nevertheless, recalling the past, in diplomatic contexts, seems to have played also an

(79) The use (and abuse) of the past in ancient literature has recently received particular attention: see e.g. PownaLL 2004; Grethlein 2010; Osmers 2013; Steinbock 2013, and the essays collected in Grethlein, Kreb 2012; Marincola, Llewellyn-Jones, Maciver 2012; Ker, Pieper 2014.

(80) There are, of course, other diplomatic speeches which refer to historical exempla, of course (see GRETHLEIN 2014, p. 336-340, for a brief discussion), but what makes the difference here is the connection between supplication and memories in a diplomatic context.

(81) FGrHist 456.

(82) See Nelson 2005; Nelson 2007; Nelson 2013.

(83) So Wooten 1973. On his assumptions, see now Rubinstein 2016, p. 79-82.

(84) See n. 79.

(85) Chaniotis 2009. 
emotional role: as I hope to clarify elsewhere ${ }^{86}$ well selected historical examples could help the envoys to increase the trust of the receiver towards the sender, while in supplicatory speeches the recollection of shared memories was especially meant to arouse the pity and the gratitude of the listeners.

For example, in Thucydides' account of Plataea's fate, which since antiquity has been considered one of his finest pieces of eloquence, ${ }^{87}$ the Plataean speech is actually part of a famous "debate", because the Theban envoys are also allowed to make a reply ${ }^{88}$ : in their peroration, the Plataean representatives invoke many arguments intended to influence the decision of the Spartans, ${ }^{89}$ but the most powerful emotional card they can play to stir the pity of the judges is that of recalling the historical-not mythical-past of their city, especially the role played by the Plataeans themselves during the Persian wars, where the Thebans sided with Xerxes. ${ }^{90}$ The past looms large in the entire speech ${ }^{91}$ : the orators, wishing to emphasise the previous good relationships between the two poleis, ${ }^{92}$ remind the Spartan judges of a well-known historical episode, when Plataea came to the aid of Sparta after the earthquake and the Helots' revolt in $464,{ }^{93}$ particular prominence is of course given to the "Spartan" victorious battle of Plataea in $479 .{ }^{94}$ But the most emotional use of these shared memories occurs at the very moment of the supplication, ${ }^{95}$ when the Plataean orators ask the Spartans to look directly at the tombs of their soldiers- "your fathers' tombs"-who fell in those fields fighting against the Persians, ${ }^{96}$ and present themselves as both "guardians" of the sacred burial place, ${ }^{97}$ and "suppliants at the graves of your fathers". ${ }^{98}$ In this way, the emotional language of supplication enables the Plataeans to link up the past ("that day on which we achieved the most glorious deeds together with your fathers") to their present situation ("on this day we are in danger of meeting the most terrible fate"), trying to elicit the piety and gratitude of the Spartans. ${ }^{99}$

(86) Gazzano forthcoming.

(87) Dion. Hal. De Thuc. 42. So Macleod 1977, p. 229: "the destiny of Plataea is one of those sufferings which for Thucydides make the war worth recording and give history the status of epic".

(88) Thucydides' account of the events leading to the Spartan conquest of Plataea: III 20-24, and 52. Speech of the Plataean representatives: 53-59; speech of the Theban envoys: 61-67; Spartan final decision: 68. On the Plataean debate (and his deliberative and pseudo-forensic character) see e.g. Gomme, HCT III, 1956, p. 337-358; Macleod 1977; Debnar 1996; GreTHLein 2012; STEINBock 2013, p. 120-123, 135-136; Bruzzone 2015; FragoulaKi 2016.

(89) Plataeans' main arguments are of a legal and moral order: innocence, justice, necessity, kinship ties. On their substantial weakness see MACLEOD 1977.

(90) On the Thebans' reply, see in particular Debnar 1996; on the image of Thebes in fifth-century Athens, see STEINBOCK 2013, p. 120-127; on fourth-century development, see especially p. 326-341.

(91) On this aspect, see especially Bruzzone 2015.

(92) On the language of friendship cf. Bruzzone 2015, p. 292-294; on that of kinship Fragoulaki 2016, p. 119-125.

(93) Thuc. III $54,5$.

(94) Mention is made of the battle of Plataea in 54,4, its aftermaths in 57,2 and then again the battle in 58-59. The Plataeans also mention, but of course en passant, their participation in the battle of Artemisium $(54,4)$, and duly underline with two implicit allusions and two open accusations the fact that the Thebans fought on the Persian side $(54,3 ; 56,5)(56,4$; $58,4)$.

(95) The supplication of the Plataeans is twofold: first, they tell the Spartans they are suppliants because they surrendered to them "with the hands outstretched in supplication-and Greek law prohibits the killing of suppliants" $(58,3)$, then their statement becomes "your suppliants at the graves of your fathers, and we call on the departed not to let us fall under the Thebans and to prevent the betrayal of their closest friends by their bitterest enemies" $(59,2)$.

(96) Debnar 1996, p. 89 notes the importance Spartans usually gave to vision and to visual signs.

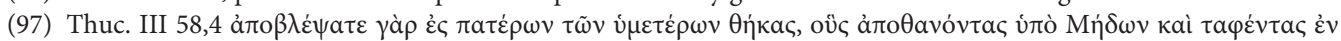

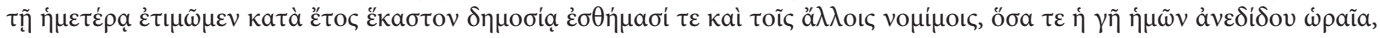

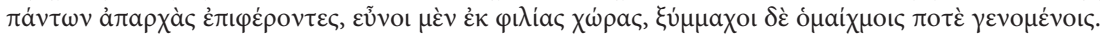

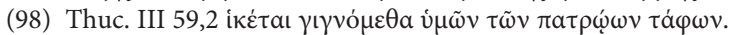

(99) BRUzzone 2015, p. 295-296 convincingly argues that "the speakers treat the past as if it were the present and the living as if they were contemporaries of the dead. They discuss the Persian War dead as if they are sentient observers of current events". 
Instead, in Isocrates' Plataicus one Plataean representative makes his appeal before the Athenian assembly some 50 years later, after the destruction of Plataea at the hands of Thebes (373 is the conventional date): ${ }^{100}$ here, the supplication opens the speech, and starts with the "canonical" eulogy of Athens as the "city of justice", with sentences like "your custom is zealously to come to the rescue of victims of injustice", and "many peoples in the past have fled to you for protection and have obtained all they craved". ${ }^{101}$ Then follows the proof (7-44), a detailed and obviously biased sketch of recent events, which eventually results in a tough attack towards the Thebans' ungrateful attitude and treacherous deeds towards the Athenians and the Plataeans alike ${ }^{102}$; finally, the orator builds his emotional appeal (45-63) on both the "historical past" (the role of Plataea during the Persian wars, the kinship ties with Athens) and mythical times, when Athens had accepted Adrastus' supplication to rescue the bodies of the fallen at Thebes, thus gaining glory and an undying reputation till the end of time. Even if in 373 Athens had lost her empire, she continued to be the "city of suppliants". ${ }^{103}$ At any rate, supplication needed emotional arguments, and these were fostered by both renewed mythical paradigms and shared historical memories.

A similar exploitation of the past, aimed at arousing gratitude and feelings of mutual engagement, and closely connected to a supplication, can be detected also in the later (thirdcentury) Presbeutikos, whose speaker presents himself as Thessalus, the son of the renowned physician Hippocrates. ${ }^{104}$ Here, however, this combination of elements takes a peculiar turn. The oration purports to be delivered before the Athenian assembly at around $407,{ }^{105}$ to dissuade Athens from an impending attack upon Cos; the speaker supplicates the Athenians not to attack his city, ${ }^{106}$ seeking to elucidate the friendship ties of his homeland with Athens through his very family, the Asclepiadai, who have always been benefactors of the city. ${ }^{107}$ Four episodes in which the Athenians were involved (the First Sacred War, Xerxes' invasion, a general plague in Greece around the last quarter of the fifth century, the Sicilian expedition) $)^{108}$ are selected to show that one or more

(100) On Platea's fate, see Ведвzot 2004.

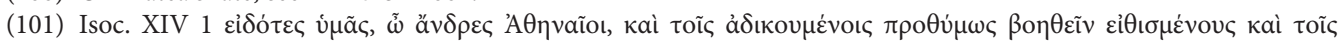

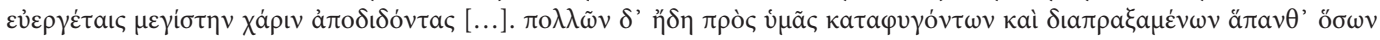

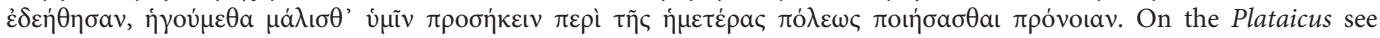
STEINBOCK 2013, p. 124, 127.

(102) On Isocrates' view of Thebes, see recently CUniBerTi 2015, with previous bibliography.

(103) See Christ 2012, p. 126-137, 154-176; STEINBock 2013, p. 187-189.

(104) On this speech ([Hippoc.] Ep. 27= Presb.), see the edition of Smith 1990 and the studies of NeLson 2005; Nelson 2007; Nelson 2012.

(105) I follow Nelson 2005, who links the Presbeutikos to an episode of the Coan historian Macareus that presented a local perspective on the final stages of the Peloponnesian War (c. 411-407), when the island was repeatedly attacked by Alcibiades (Thuc. VIII 41, 44, 108; Diod. III 41,2 and 69,5).

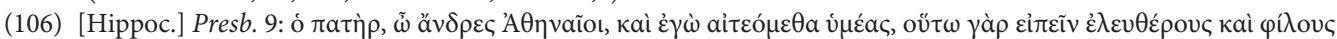

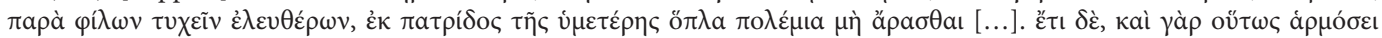

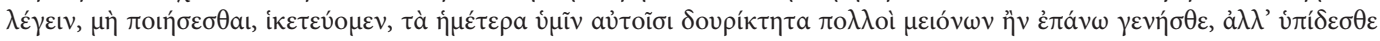

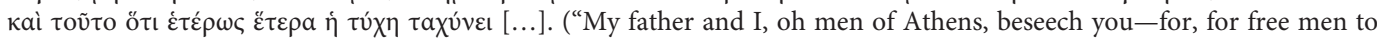
speak so, and for friends to get favors from friends is the behavoir of free men-do not rise up aggressive war from your land." [... "And further, and this will be a fitting way to speak, we beseech you, do not make our possessions your booty, if you who are many prove superior to us lesser numbers, but look on this fact, that fate speeds one thing one way and another another way"; transl. Smith).

(107) On the Asclepiadai, see Nelson 2013, with a discussion about the relationship between the Presbeutikos and the request of asylia, for the Coan Asclepieion, and its festival, celebrated in 246, when Cos sent sacred ambassadors (theoroi) throughout the Hellenic world.

(108) First Sacred War: Nebros and Chrysos (Presb. 2-4, p. 110-114 Smith); opposition to the Persian King and Artemisia of Halicarnassus (Presb. 5-6, p. 114-116 Smith); saving Greeks and the Athenians from a general plague (Hippocrates and his sons: Presb.7, p. 116-120 Smith); Thessalus' service as a doctor in the Athenian army during the Sicilian expedition (Presb. 8, p. 120 Smith). 
members of the Asclepiadai had willingly come to the aid of Athens with their medical arts; and this since "mythical times", that is, in the speaker's view, the years of the First Sacred War. ${ }^{109}$

The examples could end here, but it may be suggested that this emotional use of the past, through the revival of collective memories (or, in the Presbeutikos, family memories), to arouse pity in a diplomatic supplication, may even be traced back to Homer, whose "Embassy to Achilles", in the Iliad, might be considered as an authoritative and inspiring archetype. ${ }^{110}$ In this key episode, a real turning point in the poem, the three envoys seek to achieve their diplomatic goal-persuade Achilles to forgo his wrath-using different "diplomatic" arguments and tones. ${ }^{111}$ The most moving part is assigned to old Phoenix: his speech is emotionally charged, and it is based on family and paternal relationships. He seeks to persuade the hero with the language of supplication, ${ }^{112}$ which refers in a dual way to the past: on the one hand he reminisces about Achilles' infancy-a living past, so to say-(434-523), and on the other he uses an example, that of Meleager, belonging to a more distant age (524-599). Needless to say, this embassy too, like the three others already mentioned, failed, because Achilles refused to forgo his anger.

In conclusion, if Phoenix's plea may be considered the first literary example of the use of supplication in a diplomatic context, we are led to admit that in the Greek world this kind of "desperation diplomacy" proved in most cases useless, and this might explain its rarity in what survives concerning the relationships among the Greek poleis, at least as long as they were free from foreign domination. The coming of Rome, much more than that of Philip and Alexander, changed the habits of Greek diplomatic practice, as in 189, when the Aetolian ambassadors learned at their expense: Livy, reflecting the Roman point of view, writes that when these envoys were introduced into the Senate, "although both their own interests and their situation urged them to confess guilt or mistake, and to beg as suppliants for pardon", they offended the senators by the insolence of their speech, and "by recalling their old and forgotten services to Rome [...]; in a situation when they needed mercy, they roused only anger and hatred". ${ }^{113}$

Francesca Gazzano Università di Genova

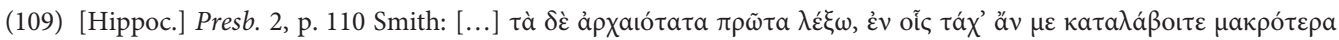

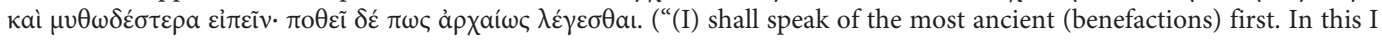
may be constraint to speak somewhat lengthily and mythologically, but the subject wants to be told in an archaic manner"; transl. Smith).

(110) Hom. Il. IX 179-657. The entire episode has been much debated, for a number of reasons (from the use of the duals on), which is not possible to take into account here. Its importance as a model of diplomatic speeches has been underlined by Dularidze 2005. On the relevance of this embassy in Herodotus' description of the Greek mission to Gelon (Hdt. VII 153-163), see Grethlein 2006.

(111) See Dularidze 2005 for a detailed analysis.

(112) See in this sense Rosner 1976; cf. now Dularidze 2005.

(113) Liv. XXXVII 49 Aetoli legati in senatum introducti, cum et causa eos sua et fortuna hortaretur, ut confitendo seu culpae seu errori veniam supplices peterent, orsi a beneficiis in populum Romanum et prope exprobrantes virtutem suam in Philippo bello et offenderunt aures insolentia sermonis et eo, vetera et oblitterata repetendo, rem adduxerunt, ut haud paulo plurium maleficiorum gentis quam beneficiorum memoria subiret animos patrum, et quibus misericordia opus erat, iram et odium irritarent. See LINDERSKI 1995 (= 2007). 


\section{Bibliography}

Arnold, P.E., 1992, “The Persuasive Style of Debates in Direct Speech in Thucydides", Hermes, 120/1, p. 44-57.

Bearzot, C., 2004, "La città che scompare. Corinto, Tespie e Platea tra autonomia cittadina e politeiai alternative", in G. Vanotti, C. Perassi (eds.), In limine. Ricerche su marginalità e periferia nel mondo greco, Milano, p. 269-286.

Bederman, D. J., 2001, International Law in Antiquity, Cambridge.

Bernek, R., 2004, Dramaturgie und Ideologie: Der politische Mythos in den Hikesiedramen des Aischylos, Sophokles und Euripides, Leipzig.

Blundell, M.W., 1989, Helping Friends and Harming Enemies. A Study in Sophocles and Greek Ethics, Cambridge.

Boedecker, D., Rafflaub, K. (eds.), 1998, Democracy, Empire and the Arts in 5th Century Athens, Cambridge MA.

Branscome, D., 2013, Textual Rivals: Self-Presentation in Herodotus' Histories, Ann Arbor.

Bruzzone, R., 2015, “Killing the Past in Thucydides' Plataean Debate”, ClPh 110/4, p. 289-300.

Buxton, R. G. A., 1982, Persuasion in Greek Tragedy, Cambridge.

Cairns, D.L., 1993, Aidôs. The Psychology and Ethics of Honour and Shame in Ancient Greek Literature, Oxford.

CaIrns, D. L., 2008, "Look Both Ways: Studying Emotion in Ancient Greek", Critical Quarterly 50, p. 43-63.

Cairns, D. L., Fulkerson, L. (eds.), 2015, Emotions between Greece and Rome, London.

Cairns, D., Nelis, D.P. (eds.), 2017, Emotions in the Classical World. Methods, Approaches, and Directions, Stuttgart.

Canali De Rossi, F., 1997, Le ambascerie dal mondo greco a Roma in età repubblicana, Roma.

Carey, C., 1994, "Rhetorical means of persuasion", in Worthington 1994, p. 26-45.

Castriota, D., 1992, Myth, Ethos, and Actuality. Official Art in Fifth-Century Athens, Madison.

CecCarelli, P., 2013, Ancient Greek Letter Writing: A Cultural History (600 BC-150 BC), Oxford.

Сналіотіs, A., 2009, "Überzeugungsstrategien in der griechischen Diplomatie. Geschichte als Argument", in A. Chaniotis, A. Kropp, C. Steinhoff (Hrsg), Überzeugungsstrategien, Berlin-Heidelberg, p. 147-166.

Сналіотіs, A. (ed.), 2011, Ritual Dynamics in the Ancient Mediterranean. Agency, Emotion, Gender, Representation, Stuttgart.

Chaniotis, A. (ed.), 2012a, Unveiling Emotions, Sources and Methods for the Study of Emotions in the Greek World, Stuttgart.

Chaniotis, A., 2012b, "Moving Stones: The Study of Emotions in Greek Inscriptions", in Chaniotis 2012a, p. 91-129.

Chaniotis, A., 2013a, "Empathy, Emotional Display, Theatricality, and Illusion in Hellenistic Historiography", in Chaniotis, DuCREy 2013, p. 53-84.

Снаniotis, A., 2013b, "Normen stärker als Emotionen? Der kulturhistorische Kontext der griechischen Amnestie", in K. Harter-Uibopuu, F. Mitthof (eds.), Vergeben und Vergessen? Amnestie in der Antike, Wien, p. 47-70.

Chaniotis, A., 2013c, "Affective Epigraphy: Emotions in Public Inscriptions of the Hellenistic Age", MedAnt 16.2 , p. $745-760$.

Chaniotis, A., 2013d, "Emotional Language in Hellenistic Decrees and Hellenistic Histories", in M. Mari, J. Thornton (eds.), Parole in movimento. Linguaggio politico e lessico storiografico nel mondo ellenistico, Pisa, p. 339-352.

Chaniotis, A., 2015, "Affective Diplomacy: Emotional Scripts between Greek Communities and Roman Authorities during the Republic", in CAIrns, Fulkerson 2015, p. 87-103.

Chaniotis, A., Ducrey, P. (eds.), 2013, Unveiling Emotions II: Emotions in Greece and Rome. Texts, Images, Material Culture, Stuttgart. 
Chaniotis, A., Kaltsas, N., Mylonopoulos, I. (eds.), A World of Emotions: Ancient Greece, 700 BC-200 AD, Oxford-New York 2017.

Christ, M.R., 2012, The Limits of Altruism in Democratic Athens, Cambridge.

Clément, M., SANgar, E. (eds.), 2018, Researching Emotions in International Relations, Cham.

Cooper, C., 2008, "Hypereides, Aristophon, and the Settlement of Keos", in C. Cooper (ed.), Epigraphy and the Greek Historians, Toronto-Buffalo-London, p. 31-46.

Cuniberti, G., 2015, "Isocrate e la storia ateniese del V secolo", in C. Bouchet, P. Giovannelli-Jouanna (eds.), Isocrate. Entre jeu rhétorique et enjeux politiques, Lyon, p. 203-216.

Damon, C., 2017, "Emotions as a Historiographical Dilemma”, in CAIRns, Nelis 2017, p. 177-194.

Debnar, P.A., 1996, “The Unpersuasive Thebans (Thucydides 3.61-67)”, Phoenix 50/2, p. 95-110.

Dularidze, T., 2005, "The Achaean Ambassadorial Mission to Achilles According to the Iliad, Book IX", Phasis 8, p. 29-35.

EILERs, C. (ed.), 2009, Diplomats and Diplomacy in the Roman World, Leiden-Boston.

Forsdy ke, S., 2005, Exile, Ostracism, and Democracy. The Politics of Expulsion in Ancient Greece, PrincetonOxford.

Fortenbaugh, W.W., 1970, “Aristotle's Rhetoric on Emotions”, AGPh 52, p. 40-70 (= Fortenbaugh 2006, p. 9-38).

Fortenbaugh, W.W., 1975, Aristotle on Emotion, London (2nd ed. 2002).

Fortenbaugh, W. W., 2006, Aristotle's Practical Side. On his Psychology, Ethics, Politics, and Rhetoric, LeidenBoston.

Fortenbaugh, W.W., 2007, “Aristotle's Art of Rhetoric”, in Worthington 2007, p. 107-123.

Fragoulaki, M., 2013, Kinship in Thucydides. Intercommunal Ties and Historical Narrative, Oxford.

Fragoulaki, M., 2016, "Emotion, Persuasion and Kinship in Thucydides: The Plataian Debate (3.52-68) and the Melian Dialogue (5.85-113)", in SANDERS, JoHnCOCK 2016, p. 113-132.

Garland, R., 2014, Wandering Greeks. The Ancient Greek Diaspora from the Age of Homer to the Death of Alexander the Great, Princeton-Oxford.

Gazzano, F., 2016, “Celebrity diplomacy? Poeti e attori nelle ambascerie delle città greche”, Ktèma 41, p. 123140.

GazzANo, F., forthcoming, "Bridging the gap. Using the past to shape good faith in Greek diplomatic speeches", paper presented at the International Conference Shaping Good Faith-Modes of Communication in Ancient Diplomacy (TOPOI-FU Berlin 11-12 October 2018), Proceedings by F. Mari, Ch. Wendt, forthcoming.

Giordano, M., 1999, La supplica. Rituale, istituzione sociale e tema epico in Omero, Napoli.

GöDde, S., 2000, Das Drama der Hikesie: Ritual und Rhetorik in Aischylos' Hiketiden, Münster.

Gotteland, S., 2001, Mythe et rhétorique: Les exemples mythiques dans le discours politique de l'Athènes classique, Paris.

Gottesman, A., 2014, Politics and the Street in Democratic Athens, Cambridge.

Gould, J.P.A., 1973, “Hiketeia”, JHS 93, p. 74-103.

Gray, B., 2015, Stasis and Stability. Exile, the Polis and Political Thought, c.404-146 BC, Oxford.

Grethlein, J., 2003, Asyl und Athen: Die Konstruktion der Identität in der griechischen Tragödie, Stuttgart.

Grethlein, J., 2006, “The Manifold Uses of the Epic Past: The Embassy Scene in Herodotus 7.153-63”, AJPh $127 / 4$, p. 485-509.

Grethlein, J., 2010, The Greeks and their Past: Poetry, Oratory and History in the Fifth Century BCE, Cambridge.

Grethlein, J., 2012, “The Use and Abuse of History in the Plataean Debate (Thuc. 3.52-68)”, in Grethlein, KREB 2012, p. 67-85.

Grethlein, J., 2014, “The Value of the Past Challenged: Myth and Ancient History in the Attic Orators”, in Ker, Pieper 2014, p. 326-354. 
Grethlein, J., Kreb, C.B., 2012, (eds.), Time and Narrative in Ancient Historiography. The 'Plupast' from Herodotus to Appian, Cambridge.

Griffith-Williams, B., 2016, "Rational and Emotional Persuasion in Athenian Inheritance Cases", in SANDERS, JOHNCOCK 2016, p. 41-56.

Hall, T.H., 2015, Emotional Diplomacy. Official Emotion on the International Stage, Ithaca NY.

Hanink, J., 2013, “Epitaphioi Mythoi and Tragedy as Encomium of Athens”, TC 5, p. 289-317.

Harder, M. A., Stöppelkamp, K. (eds.), 2016, Emotions in Antiquity: Blessing or Curse?, Leuven-Paris-Bristol. Hau, L. M., 2016, Moral History from Herodotus to Diodorus Siculus, Edinburgh.

Heath, M., 1990, “Justice in Thucydides' Athenian Speeches”, Historia 39/4, p. 385-400.

Hornblower, S., 1991, A Commentary on Thucydides, I, Oxford.

Hunt, P., 2010, War, Peace, and Alliance in Demosthenes' Athens, Cambridge.

Johnstone, S., 1999, Disputes and Democracy. The Consequences of Litigation in Ancient Athens, Austin.

Jones, C.P., 1999, Kinship Diplomacy in the Ancient World, Cambridge.

Jönsson, Ch., Hall, M., 2005, The Essence of Diplomacy, Houndmills, Basingstoke, New York.

Karavites, P., 1984, “GreekInterstate Relations and Moral Principles in the Fifth Century BC”, PP39,p. 161-192.

Kennedy, G. A., 1963, The Art of Persuasion in Greece, Princeton.

Ker, J., PiePer, Ch. (eds.), 2014, Valuing the Past in the Greco-Roman World, Leiden-Boston.

KIEnAst, D., 1973, s.v. Presbeia, RE Suppl. XIII, coll. 495-627.

Konstan, D., 1999, “The Tragic Emotions”, Comparative Drama 33/1, p. 1-21.

Konstan, D., 2006, The Emotions of the Ancient Greeks: Studies in Aristotle and Classical Literature, TorontoBuffalo-London.

Konstan, D., 2007, "Rhetoric and Emotion", in Worthington 2007, p. 411-425.

Kurbalija, J. (ed.), 2013, Persuasion. The Essence of Diplomacy. A Publication in Honour of Professor Dietrich Kappeler, Geneva-Msida.

LaCurse Munteanu, D., 2012, Tragic pathos: pity and fear in Greek philosophy and tragedy, Cambridge.

LaCurse Munteanu, D., 2017, “The Paradox of Literary Emotion: An Ancient Greek Perspective and Some Modern Implications”, Nuntius Antiquus, 13/2, p. 263-283.

LANZA, D., 1997, La disciplina dell'emozione, Milano.

LApini, W., 1997, Commento all'Athenaion Politeia dello Pseudo-Senofonte, Firenze.

LAPINI, W., 2013, "Il carteggio fra Dario ed Eraclito (Diog. Laert. 9.13-14)", in W. Lapini, Testi frammentari

e critica del testo. Problemi di filologia filosofica greca, Roma, p. 23-36.

Lauritzen, E.A., 2014, "Persuading Through Pity and Fear: Aristotle's Account of the Emotions in the Rhetoric", Nordlit 33, p. 139-158.

Linderski, J., 1995, “Ambassadors Go to Rome”, in Ed. Frézouls, A. Jacquemin (eds.), Les Relations Internationales. Actes du Colloque de Strasbourg 15-17 juin 1993, Paris 1995, p. 453-78 (= in J. LINDERSKI, Roman Questions. Selected Papers, II, Stuttgart, 2007, p. 40-60, with addenda).

Lionetti, R., forthcoming, "Moral Obligations towards Refugees: Herodotus and the Ancient Mediterranean Practices of Supplication", paper presented at the Conference Refuge and Refugee in the Ancient World (November 11-12, 2016), Columbia University, New York.

Loraux, N., 1986, The Invention of Athens. The Funeral Oration in the Classical City, Cambridge, MA (orig. ed., L'invention d'Athènes. Histoire de l'oraison funèbre dans la "cité classique", Paris 1981).

Low, P., 2007, Interstate Relations in Classical Greece: Morality and Power, Cambridge.

Macleod, C.W., 1977, “Thucydides' Plataean Debate”, GRBS 18, p. 227-246 (= C. W. Macleod, Collected Essays, Oxford 1983, p. 103-112).

Magnetto, A., 2013, "Ambasciatori plenipotenziari delle città greche in età classica ed ellenistica: terminologia e prerogative”, in M. Mari, J. Thornton (eds.), Parole in movimento. Linguaggio politico e lessico storiografico in età ellenistica, Pisa-Roma, p. 223-241. 
Marincola, J., Llewellyn-Jones, L., Maciver, C. (eds.), 2012, Greek Notions of the Past in the Archaic and Classical Eras. History without Historians, Edinburgh.

McDonald, M., 2007, “Rhetoric and Tragedy: Weapons of Mass Persuasion”, in Worthington 2007, p. 473489.

Meineck, P., 2017, Theatrocracy: Greek Drama, Cognition, and the Imperative for Theatre, London-New York. Mills, S., 1997, Theseus, Tragedy and the Athenian Empire, Oxford.

Morrison, J.V., 1999, "Preface to Thucydides: Rereading the Corcyrean Conflict (1.24-55)", ClAnt 18/1, p. $94-131$.

Mosley, D. J., 1973, Envoys and Diplomacy in Ancient Greece, Wiesbaden.

Naiden, F. S., 2006, Ancient Supplication, Oxford.

Nelson, E.D., 2005, “Coan Promotions and the Authorship of the Presbeutikos", in Ph. Van der Eijk (ed.), Hippocrates in Context, Leiden-Boston, p. 209-238.

Nelson, E.D., 2007, "Hippocrates, Heraclids, and the 'Kings of the Heracleidai': Adaptations of Asclepiad History by the Author of the Presbeutikos", Phoenix 61/3-4, p. 234-246.

Nelson, E. D., 2013, “Coan Asylia: Small-state Diplomacy and the Hippocratic Legend”, in F. De Angelis (ed.), Regionalism and Globalism in Antiquity. Exploring Their Limits, Leuven-Paris-Walpole, p. 247-266.

Orwin, C., 1994, The Humanity of Thucydides, Princeton.

Osmers, M., 2013, "Wir aber sind damals und jetzt immer die gleichen": Vergangenheitsbezüge in der polisübergreifenden Kommunikation der klassischen Zeit, Stuttgart.

Papaioannou, S., Serafim, A., Da Vela, B. (eds.), 2017, The Theatre of Justice. Aspects of Performance in Greco-Roman Oratory and Rhetoric, (Mnemosyne Suppl. 403), Leiden-Boston.

Parker, R., 1983, Miasma. Pollution and Purification in early Greek Religion, Oxford.

Patterson, L., 2010, Kinship Myth in Ancient Greece, Austin.

Pedrina, M., 2017, La supplication sur les vases grecs. Mythes et images, Pisa-Roma.

Piccirilli, L., 2002, L'invenzione della diplomazia nella Grecia antica, Roma.

Pownall, F., 2004, Lessons from the Past. The Moral Use of History in Fourth-Century Prose, Ann Arbor.

Proietti, G., 2015, “Beyond the 'Invention of Athens'. The 5th Century Athenian Tatenkatalog as Example of 'Intentional History”, Klio 97/2, p. 516-538.

Price, M.E., 2009, Rethinking Asylum: History, Purpose, and Limits, Cambridge.

Rhodes, P.J., 1993, A Commentary on the Aristotelian Athenaion Politeia, Oxford (1st ed. 1981).

Rosner, J.A., 1976, “The Speech of Phoenix: Iliad 9.434-605”, Phoenix, 30/4, p. 314-327.

Rubinstein, L., 2013, “Spoken Words, Written Submissions, and Diplomatic Conventions: The Importance and Impact of Oral Performance in Hellenistic Inter-polis Relations”, in Ch. Kremmydas, K. Tempest (eds.), Hellenistic Oratory. Continuity and Change, Oxford, p. 165-200.

Rubinstein, L., 2016, "Envoys and ethos: team speaking by envoys in classical Greece", in M. Edwards, P. Ducrey, P. Derron (eds.), La rhétorique du pouvoir. Une exploration de l'art oratoire délibératif grec, (Entretiens Hardt, LXII), Vandoeuvres, p. 79-128.

SAnders, E., 2016, "Persuasion Through Emotions in Athenian Deliberative Oratory", in SANders, Johncock 2016, p. 57-74.

SAnders, E., Johncock, M. (eds.), 2016, Emotion and Persuasion in Classical Antiquity, Stuttgart.

Scott, L., 2005, Historical Commentary on Herodotus, Book 6, Leiden-Boston.

ServadeI, C., 2005, C. La figura di Theseus nella ceramica attica: iconografia e iconologia del mito nell'Atene arcaica e classica, Bologna.

Shapiro, H.A., (2012), "Attic Heroes and the Construction of the Athenian Past in the Fifth Century", in Marincola, Llewellyn-Jones, Maciver 2012, p, 160-182. 
Sмiтн, W. D., 1990, Hippocrates. Pseudepigraphic Writings: Letters, Embassy, From the Altar, Decree. LeidenNew York-Köln.

Steinвock, B., 2013, Social Memory in Athenian Public Discourse. Uses and Meanings of the Past, Ann Arbor. STANFORD, W.B., 1983, Greek tragedy and the emotions: an introductory study, London-New York.

TAPLIN, O., 1978, Greek Tragedy in Action, London-New York.

Tsingarida, A., 2001, "Soif d'émotions. La représentation des sentiments dans la céramique attique des $\mathrm{VI}^{\mathrm{e}}$ et $V^{\text {e }}$ siècles av. n. ère”, $R B P h, 79 / 1$, p. 5-30.

Tzanetou, A., 2012, City of Suppliants. Tragedy and the Athenian Empire, Austin.

Usher, S., 2007, "Symbouleutic Oratory", in Worthington 2007, p. 220-235.

Vannicelli, P., 2017, Erodoto. Le Storie. Libro VII, a cura di P. Vannicelli, A. Corcella, Milano.

Visvardi, E., 2015, Emotion in Action. Thucydides and the Tragic Chorus, Leiden-Boston.

Wong, S., 2016, "Emotions and the Communication of Intentions in Face-to-face Diplomacy", European Journal of International Relations, 22/1, p. 144-167.

Wooten, C., 1973, “The Ambassador’s Speech: a Particular Genre of Oratory”, QJS 59, p. 209-212.

Worthington, I. (ed.), 1994, Persuasion: Greek Rhetoric in Action, London-New York.

Worthington, I. (ed.), 2007, A Companion to Greek Rhetoric, Malden-Oxford-Victoria.

Zaccarini, M., 2017, The Lame Hegemony. Cimon of Athens and the Failure of Panhellenism, ca. 478-450 BC, Bologna.

ZaLI, V., 2015, The Shape of Herodotean Rhetoric. A Study of the Speeches in Herodotus' Histories, with Special Attention to Books 5-9, Leiden-Boston.

Zelnick-Abramovitz, R., 1998, "Supplication and Request: Application by Foreigners to the Athenian Polis", Mnemosyne 51, p. 554-573. 